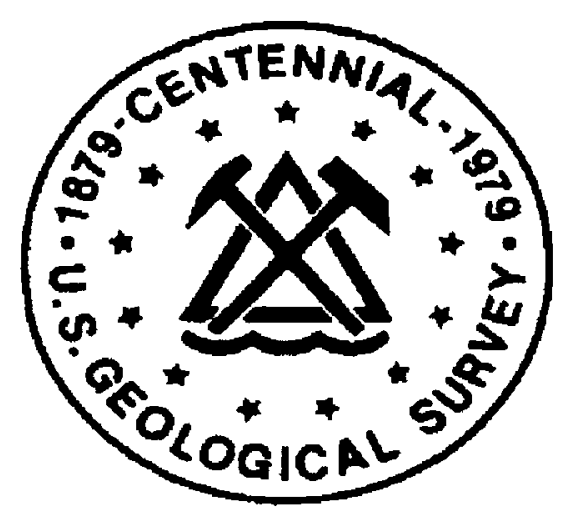

\title{
BRANCH OF PETROLEUM GEOLOGY BIBLIOGRAPHY
}

1994

Compiled by

Shirley A. Oscarson'

Open-File Report 95-246

This report is preliminary and has not been reviewed for conformity with U.S. Geological Survey editorial standards or with the North American Stratigraphic Code. Any use of trade, product, or firm names is for descriptive purposes only and does not imply endorsement by the U.S. Government.

${ }^{1}$ Denver, Colorado 
Agena, W.F., Lee, M.W., Miller, J.J., and Hutchinson, D.R., 1994, Lake Baikal-1992Processing of multichannel seismic reflection data: U.S. Geological Survey OpenFile Report 94-263, 44 p.

Ahlbrandt, T.S. and Ball, S.F., 1994, Techniques for the identification of bypassed, lowresistivity, shallow, underpressured oil reservoirs in Wyoming [abs.]: American Association of Petroleum Geologists Hedberg Research Conference, Denver, p. 1-2.

Ahlbrandt, T.S., Gautier, D.L., and Bader, Talat, 1994, Low-angle eolian deposits in coastal settings-Significant Rocky Mountain exploration targets: The Mountain Geologist, v. 31, no. 4, p. 95-114.

Ball, M.M., 1994, Forest City Basin province (119), in Powers, R.B., ed., Petroleum exploration plays and resource estimates, 1989, onshore United States-Region 7, Mid-Continent: U.S. Geological Survey Open-File Report 94-24, p. 61-62.

Barker, C.E., 1994, Natural desorption of gas from exhumed coaly rocks as a cause of overpressuring in eroding basins of the Rocky Mountain region-An example from the Madden anticline, Wind River Basin, Wyoming [abs.]: Nordic Symposium, Gothenburg, Sweden, 1994, Abstracts, p. 13-16.

Barker, C.E., 1994, An overview of the petroleum geology and possible areas of hydrocarbons accumulation in the Malheur-Jordan-Andrews resource areas, southeastern Oregon: Administrative Report to Bureau of Land Management, $11 \mathrm{p}$.

Barker, C.E., 1994, Thermal and petroleum generation history of the Mississippi Eleana Formation and Tertiary source rocks, Yucca Mountain area, southern Nye County, Nevada: U.S. Geological Survey Open-File Report 94-161, 45 p.

Barker, C.E., 1994, Vitrinite reflectance of whole-rock versus dispersed organic matter concentrate mounts-What's the difference?: Society of Organic Petrology Abstracts, v. 11, p. 1-4.

Barker, C.E., and Coury, A.B., comps., 1994, Abstracts of the U.S. Geological Survey, Central Region-1994 Poster Review: U.S. Geological Survey Open-File Report 94-670, 28 p.

Barker, C.E., and Crysdale, B.L., 1994, Natural desorption of gas as a cause of overpressuring in the Madden anticline, Wind River basin, Wyoming Wind River Basin, Wyoming: Eleventh Annual International Pittsburgh Coal Conference, 1994, Proceedings, v. 2, p. 1111-1116.

Barker, C.E., and Pawlewicz, M.J., 1994, Calculation of vitrinite reflectance from thermal histories and peak temperatures-A comparison of methods, chap. 14 of Mukhopadhyah, P.K., and Dow, W.G., eds., Vitrinite reflectance as a maturity parameter-Applications and limitations: American Chemical Society Symposium Series 570, p. 216-229. 
Barker, C.E., Palacas, J.G., Threlkeld, C.N., and Daws, T.A., 1994, Gas chromatography and Rock-Eval pyrolysis analyses of some well cuttings and cores from Nevada: U.S. Geological Survey Open-File Report 94-157, 8 p.

Barton, C.C., 1994, Fractal size and spatial distribution of hydrocarbon accumulationsImplications for resource assessment and exploration strategies [abs.]: American Association of Petroleum Geologists Annual Convention, Denver, Colorado, 1994, Official Program, v. 3, p. 100.

Barton, C.C., Nishenko, S.P., Tebbens, S.F., and Loeb, W.A., 1994, Fractal scaling and forecasting of the size and frequency for Florida hurricanes 1886-1991 and of U.S. hurricane financial loss [abs.]: Santa Fe Institute Workshop, Santa Fe, New Mexico, 1994, Abstracts, p. 1.

Bird, K.J., 1994, The Ellesmerian petroleum system, North Slope, Alaska, USA, in Magoon, L.B., and Dow, W., eds., The petroleum system-From source to trap: American Association of Petroleum Geologists Memoir 60, p. 339-358.

Bostick, N.Y. , and Daws, T.A., 1994, Relationships between data from Rock-Eval pyrolysis and proximate, ultimate, petrographic, and physical analyses of 142 diverse U.S. coal samples: Organic Geochemistry, v. 21, no. 1, p. 35-49.

Bredehoeft, J.D., Wesley, J.B., and Fouch, T.D., 1994, Simulations of the origin of fluid pressure, fracture generation, and the movement of fluids in the Unita Basin, Utah: American Association of Petroleum Geologists Bulletin, v. 78, no. 11, p. 1729-1747.

Brenner, R.L. and Peterson, J.A., 1994, Cyclic sedimentation in Jurassic sequences, northern portion of the western interior, USA [abs.]: American Association of Petroleum Geologists Annual Convention, Denver, 1994, Official program, v. 3, p. 110.

Brenner, R.L. and Peterson, J.A., 1994, Jurassic sedimentary history of the northern portion of the Western Interior seaway, U.S.A., in Caputo, M.V., Peterson, J.A., and Franczyk, K.J., eds., Mesozoic systems of the Rocky Mountain region, USA: Society of Sedimentary Geology, Rocky Mountain Section, Special Publication, p. 217-232.

Burruss, R.C. and Reynolds, J., 1994, Nucleation, growth, and dissociation of methane gas hydrate-Microscope observations in a natural fluid inclusion in fluorite: U.S. Geological Survey Open-File Video 93-388.

Caputo, M.V., Peterson, J.A., and Franczyk, K.J., eds., 1994, Mesozoic systems of the Rocky Mountain region, United States: Society of Sedimentary Geology, Rocky Mountain Section, Special Publication, $536 \mathrm{p}$.

Charpentier, R.R., 1994, Cherokee Platform province (118), in Powers, R.B., ed., Petroleum exploration plays and resource estimates, 1989, onshore United States-Region 7, Mid-Continent: U.S. Geological Survey Open-File Report 94-24, p. 53-60. 
Charpentier, R.R., 1994, Sedgwick Basin province (122), in Powers, R.B., ed., Petroleum exploration plays and resource estimates, 1989, onshore United States-Region 7, Mid-Continent: U.S. Geological Survey open-File Report 94-24, p. 71-75.

Charpentier, R.R., Völgyi, László, Dolton, G.L., Mast, R.F., and Pályi, András, 1994, Undiscovered recoverable oil and gas resources, chap. 16 of-Teleki, P.G., and others, eds., Basin analysis in petroleum exploration: Netherlands, Kluwer Academic Publishers, p. 305-319.

Clayton, J.L., and Koncz, István., 1994, Geochemistry of natural gas and carbon dioxide in the Békés basin-Implications for exploration in Teleki, Paul, and others, eds., Basin analysis in petroleum explorations: Netherlands, Kluwer Academic Publishers, p. 187-199.

Clayton, J.L., and Koncz, István, 1994, Petroleum geochemistry of the Zala basin, Hungary: American Association of Petroleum Geologists Bulletin, v. 78, no. 1, p. 1-22.

Clayton, J.L., Koncz, I. King, J.D., and Tatar, E., 1994, Organic geochemistry of crude oils and source rocks, Békés basin, in Teleki, P. and others, eds., Basin analysis in petroleum exploration: Netherlands, Kluwer Academic Publishers, p. 161-185.

Clayton, J.L., Spencer, C.W., and Koncz, Istvan, 1994, Tótkomlós-Szolnok(.) Petroleum system of southeastern Hungary, chap. 35 of-Magoon, L.B., and Dow, W.C., eds., The petroleum system-From source to trap: American Association of Petroleum Geologists Memoir 60, p. 587-598.

Cole, R.B., and Stanley, R.G., 1994, Sedimentology of subaqueous volcaniclastic sediment gravity flows in the Neogene Santa Maria basin, California: Sedimentology, v. 41, p. $37-54$.

Collett, T.S., 1994, Geologic controls on gas hydrate distribution [abs.]: Quaternary Geology Society of Canada Newsletter, May 1994, p. 1.

Collett, T.S., 1994, Permafrost-associated gas hydrate accumulations, in Sloan, E.D., Jr., Happel, J., and Hnatow, M.A., eds., International Conference on Natural Gas Hydrates: Annals of the New York Academy of Sciences, v. 715, p. 247-269.

Collett, T.S., 1994, Secondary gas migration within the Prudhoe Bay-Kuparuk River area of northern Alaska [abs.]: American Association of Petroleum Geologists Annual Convention, Denver, Colorado, 1994, Official Program, v. 3, p. 125.

Cortini, Massimo and Barton, C.C., 1994, Chaos in geomagnetic reversal records-A comparison between Earth's magnetic field data and model disk dynamo data: Journal of Geophysical Research, v. 99, no. B9, p. 18,021-18,033.

Crovelli, R.A., 1994, The generalized 20/80 law using probabilistic fractals applied to petroleum field size, in Papers and extended abstracts for technical programs: International Association for Mathematical Geology Annual Conference, Mont Tremblant, Quebec, Canada, 1994, p. 100-101. 
Crovelli, R.A., 1994, Probabilistic and statistical relationships between number of vehicles and number of visitors at a geologic site in a national park: U.S. Geological Survey Open-File Report 94-560, 14 p.

Crovelli, R.A., 1994, Probabilistic fractal analysis of petroleum resources [abs.] , in Natural Resources, Economic Development, and the Environment-The Role of Management Science: The Institute of Management Sciences XXXII International Meeting, Anchorage, Alaska, 1994, p. 103.

Crovelli, R.A., 1994, Probabilistic relationships between number of vehicles and number of visitors at a geologic site in a national park, in Barker, C.E., and Coury, A.B., comps., Abstracts of the U.S. Geological Survey, Central Region, 1994 Poster Review: U.S. Geological Survey Open-File Report 94-670, p. 9.

Crovelli, R.A., and Balay, R.H., 1994, Geologic model, probabilistic methodology and computer programs for petroleum resource assessment, chap. 15 of-Teleki, P.G., and others, eds., Basin analysis in petroleum exploration: Netherlands, Kluwer Academic Publishers, p. 295-304.

Crovelli, R.A., and Barton, C.C., 1994, Fractals and the Pareto distribution applied to petroleum accumulation-size distributions, in Barton, C.C., and La Pointe, P.R., eds., Fractals in petroleum geology and earth processes: New York, Plenum Press, p. 5972.

Crysdale, B.L., Williams-Stroud, S., and Nuccio, V.F., 1994, Thermal and burial history reconstruction-A comparison of geothermometers using examples from the Paradox basin, Utah and Colorado [abs.]: Geological Society of America, Abstracts with program, v. 26, p. 8 .

Cunningham, K.I. and Collett, T.S., 1994, Surficial expression of thermogenic gas migration over the Eileen Fault zone, North Slope basin, northern Alaska [abs.]: American Association of Petroleum Geologists Hedberg Conference, Vancouver, 1994, Proceedings, p. 32-33.

Cunningham, K.I., Northup, D.E., Pollastro, R.M., Wright, W.G., and LaRock, E.J., 1994, Bacterial and fungal habitation in Lechuguilla Cave, Carlsbad Caverns National Park, New Mexico-Possible biologic origin of condensation-corrosion residues, in Sasowsky, I.D., and Palmer, M.V., eds., Breakthrough in karst geomicrobiology and redox geochemistry; Abstracts and field-trip guide: Karst Waters Institute Special Publication 1, p. 13-14.

Davis, L.E., Webster, G.D., and Dyman, T.S., 1994, Correlation of the West Canyon, Lake Point, and Bannock Peak limestones (Upper Mississippian to Middle Pennsylvanian), basal formations of the Oquirrh Group, northern Utah and southeastern Idaho: U.S. Geological Survey Bulletin 2088, 30 p.

Dillon, W.P., Lee, M.W., and Coleman, D.F., 1994, Identification of marine hydrates in situ and their distribution off the Atlantic Coast of the United States: Annals of the New York Academy of Sciences, v. 715, p. 364-380. 
Doebrich, J.L., Albino, G.V., Barker, C.E., and others, 1994, Resource assessment of the Bureau of Land Management's Winnemucca District and Surprise Resource area, northwest Nevada and northeast California-An interim project status report: U.S. Geological Survey Open-File Report 94-712, 100 p.

Dolton, G.L. and Finn, T.M., 1994, Nemaha Uplift province (120), in Powers, R.B., ed., Petroleum exploration plays and resource estimates, 1989, onshore United StatesRegion 7, Mid-Continent: U.S. Geological Survey Open-File Report 94-24, p. 63-68.

Dyman, T.S., Cobban, W.A., Fox, J.E., Hammond, R.H., Nichols, D.J., Perry, W.J., Jr., Porter, K.W., Rice, D.D., Setterholm, D.R., Shurr, G.W., Tysdal, R.G., Haley, J.C., and Campen, E.B., 1994, Cretaceous rocks from southwestern Montana to southwestern Minnesota, northern Rocky Mountains, and Great Plains region, in Shurr, G.W., Ludvigson, G.A., and Hammond, R.H., eds., Perspectives on the eastern margin of the Cretaceous Western Interior basin: Geological Society of America Special Paper 287, p. 5-26.

Flores, R.M., Keighin, C.W., and Roberts, S.B., 1994, Road log and general geology of the Bighorn Basin, Wyoming, in Flores, R.M., Mehring, K.T., Jones, R.W., and Beck, T.L., eds., Organics and the Rockies field guide: Wyoming Geological Survey Public Information Circular No. 33, p. 109-123.

Flores, R.M., Keighin, C.W., and Roberts, S.B., 1994, Road log and general geology of the northwestern Powder River Basin, Wyoming and Montana, in Flores, R.M., Mehring, K.T., Jones, R.W., and Beck, T.L., eds., Organics and the Rockies field guide: Wyoming Geological Survey Public Information Circular No. 33, p. 149-152.

Flores, R.M., Keighin, C.W., and Roberts, S.B., 1994, Road log and general geology of the Wind River Basin, Wyoming, in Flores, R.M., Mehring, K.T., Jones, R.W., and Beck, T.L., eds., Organics and the Rockies field guide: Wyoming Geological Survey Public Information Circular No. 33, p. 39-52.

Fouch, T.D., Carter, L.D., Kunk, M.J., Smith, C.A.S., and White, J.M., 1994, Miocene and Pliocene lacustrine and fluvial sequences, Upper Ramparts and Canyon Village, Porcupine River, east-central Alaska: Quaternary International, v. 22/23, p. 11-30.

Fouch, T.D., Nuccio, V.F., Anders, D.E., Rice, D.D., Pitman, J.K., and Mast, R.F., 1994, Green River (!) Petroleum System, Uinta Basin, Utah, U.S.A., chap. 25 of Magoon, L.B., and Dow, W.C., eds., The Petroleum System-From Source to Trap: American Association of Petroleum Geologists Memoir 60, p. 399-421.

Fouch, T.D., Schmoker, J.W., Boone, L.E., Wandrey, C.J., Crovelli, R.A., and Butler, W.C., 1994, Nonassociated gas resources in low-permeability sandstone reservoirs, Lower Tertiary Wasatch Formation, and Upper Cretaceous Mesaverde Group, Uinta Basin, Utah: U.S. Department of Energy Technical Report , DE-AT21-93MC30139, 61 p. 
Fouch, T.D., Schmoker, J.W., Johnson, R.C., and Spencer, C.W., 1994, Continuous and discrete gas plays-Where, why, and how much, Uinta and Piceance basins, Utah and Colorado, in First Biennial Conference on natural gas in the western United States: Rocky Mountain Association of Geologists and Colorado Oil and Gas Association, 1994, Lakewood, Colorado, 4 p.

Fouch, T.D., Wandrey, C.J., Taylor, D.J., Butler, W.C., Miller, J.J., Prensky, S.E., Boone, L.E., Schmoker, J.W., Crovelli, R.A., and Beeman, W.R., 1994, Oil and gas resources of U.S. Naval Oil Shale Reserves 1 and 3, Colorado, and Reserve 2, Utah: U.S. Geological Survey Open-File Report 94-427, 158 p.

Frederiksen, N.O., Edwards, L.E., Fouch, T.D., Carter, L.D., and Collett, T.S., 1994, Palynomorph biostratigraphy of Eocene samples from the Sagavanirktok Formation at Franklin Bluffs, North Slope of Alaska: U.S. Geological Survey Open-File Report 94-653, $32 \mathrm{p}$.

Gautier, D.L., Mast, R.F., Dolton, G.L., and Schmoker, J.W., 1994, U.S. Geological Survey methodology for the 1995 National Assessment [abs.]: American Association of Petroleum Geologists 1994 Annual Convention, Denver, Colorado, Official Program, v. 3, p. 153.

Grow, J.A., Barker, C.E., and Harris, A.G., 1994, Oil and gas exploration near Yucca Mountain, southern Nevada: American Nuclear Society Conference, Las Vegas, Nevada, 1994, Proceedings, p. 1298-1315.

Grow, J.A., Potter, C.J., and Miller, J.J., 1994, Seismic reflection studies in east-central Nevada [abs.]: American Association of Petroleum Geologists Annual Convention, Denver, Official program, 1994, v. 3., p. 160.

Gwilliam, W.J., Taylor, D.J., Latham, G.V., Krehbiel, S.C., Stanley, W.D., and Westhusing, W.J., 1994, Deep seismic reflection studies in the Pacific Northwest United States, data visualization disc: U.S. Geological Survey Digital Data Series 16, CD-ROM, A \& $B$ disks.

Henry, M.E., Ball, M.M., and Frezon, S.E., 1994, Anadarko Basin province (115), in Powers, R.B., ed., Petroleum exploration plays and resource estimates, 1989, onshore United States-Region 7, Mid-Continent: U.S. Geological Survey Open-File Report 94-24, p. 11-33.

Hester, T.C. and Schmoker, J.W., 1994, Comparison of regional trends of sandstone and carbonate porosity [abs.]: American Association of Petroleum Geologists Annual Convention, Denver, Official program, 1994, v. 3., p. 170.

Higley, D.K., 1994, Cambridge Arch-Central Kansas Uplift province (117), in Powers, R.B., ed., Petroleum exploration plays and resource estimates, 1989, onshore United States-Region 7, Mid-Continent: U.S. Geological Survey Open-File Report 94-24, p. 45-52. 
Higley, D.K., 1994, 3-D fluid-flow model of the House Creek field, Powder River basin, Wyoming [abs.]: American Association of Petroleum Geologists Annual Convention, Denver, Official program, 1994, v. 3., p. 171.

Howell, D.G., 1994, Principles of Terrane Analysis, New applications for global tectonics; 2nd edition, Chapman and Hall, London, England, 246 p.

Isaacs, C.M., Piper, D.Z., and Tennyson, M.E., 1994, Depositional setting of a classic sourcerock revisited--The Monterey Formation of California [abs.]: Canadian Society of Petroleum Geologists annual Meetting, Calgary, Canada, 1994, Abstract volume, unpaginated.

Johnson, R.C., Flores, R.M., Szmajter, Richard, and Finn, T.M., 1994, A preliminary study of coal-forming environments during deposition of the Paleocene Fort Union Formation, Wind River Basin, Wyoming [abs.]: Society for Organic Petrology Abstracts, v. 11, p. 48.

Johnson, R.C., Flores, R.M., Szmajter, Richard, and Finn, T.M., 1994, A preliminary study of coal-forming environments during deposition of the Paleocene Fort Union Formation, Wind River Basin, Wyoming, in Flores, R.M., Mehring, K.T., Jones, R.W., and Beck, T.L., eds., Organics and the Rockies Field Guide: Wyoming State Geological Survey Public Information Circular No. 33, p. 69-81.

Johnson, R.C., and Nuccio, V.F., 1994, Surface vitrinite reflectance study of the Uinta and Piceance basins and adjacent areas, eastern Utah and western ColoradoImplications for the development of Laramide basins and uplifts: U.S. Geological Survey Bulletin 1787-DD, $38 \mathrm{p}$.

Johnson, R.C., Rice, D.D., and Fouch, T.D., 1994, Gas migrating from basin-center lowpermeability hydrocarbon accumulations in the Rocky Mountain basins-Where does it go? [abs.]: American Association of Petroleum Geologists Annual Convention, Denver, Official program, 1994, v. 3., p. 181.

Johnson, S.Y., and Stanley, R.G., 1994, Sedimentology of the conglomeratic lower member of the Lospe Formation (lower Miocene), Santa Maria basin, California: U.S. Geological Survey Bulletin 1995-D,E, p. D1-D21.

Johnsson, M.J., and Howell, D.G., 1994, Generalized thermal maturity map of Alaska, U.S. Geological Survey Miscellaneous Field Investigation, 1:2,500,000, 1 sheet.

Kaplinski, M.A., Hazel, J.E., Jr., Beus, S.S., Bjerrum, C.J., Rubin, D.M., and Stanley, R.G., 1994, Structure and evolution of the "Dead Chub Eddy" Sand Bar, Colorado River, Grand Canyon, Arizona [abs.]: Geological Society of America Abstracts with programs, v. 26, no. 6, p. 21.

Keighin, C.W., 1994, Pre-field trip route from Jackson to Riverton, in Flores, R.M., Mehring, K.T., Jones, R.W., and Beck, T.L., eds., Organics and the Rockies Field Guide: Wyoming Geological Survey Public Information Circular No. 33, p. 31-37. 
Keighin, C.W., and Flores, R.M., 1994, Characteristics of oil-saturated fluvial channel sandstone reservoirs, Paleocene Upper Fort Union Formation, south-central Wind River Basin, Wyoming, in Flores, R.M., Mehring, K.T., Jones, R.W., and Beck, T.L., eds., Organics and the Rockies Field Guide: Wyoming Geological Survey Public Information Circular No. 33, p. 99-107.

Keighin, C.W. and Flores, R.M., 1994, Late Cretaceous to Paleocene clastic reservoir rocks, Wind River basin, Wyoming [abs.]: Geological Society of America Abstracts with programs, v. 26, no. 6, p. 22.

Keighin, C.W., Flores, R.M., and Rowland, Terry, 1994, Paragenetic perplexity-Causes and cures for a carbonate concretionary zone, Beulah-Zap coal, Williston basin, North Dakota [abs.]: Society for Organic Petrology Abstracts, v. 11, p. 51 25-30, 1994.

King, J.D., Yang, Jianqiang, and Pu, Fan, 1994, Thermal history of the periphery of the Junggar basin, northwestern China: Organic Geochemistry, v. 21, no. 3/4, pp. 393405.

Kingston, John, 1994, Undiscovered petroleum of southern South America: U.S. Geological Survey Open-File Report 94-559, 464 p.

Koopmans, M.P., Lewan, M.D., Sinninghe-Damste, J.S., and de Leeuw, J.W., 1994, Thermally induced transformations of organic sulfur compounds and sulfur-rich geomacromolecules as revealed by hydrous pyrolysis [abs.]: American Chemical Society, Geochemistry Division, 208th National Meeting, Washington, D.C., 1994, Abstract No. 63.

Koopmans, M.P., Sinninghe-Damste, J.S., Lewan, M.D., and de Leeuw, J.W., 1994, Distinct precursors for pristane and phytane in the marine environment-Impact on the rationale and use of the $\mathrm{pr} / \mathrm{ph}$ ratio [abs.]: American Chemical Society, Geochemistry Division, 208th National Meeting, Washington, D.C., 1994, Abstract No. 97.

Kopaska-Merkel, D.C., Mann, S.D., and Schmoker, J.W., 1994, Controls on reservoir development in a shelf carbonate- Upper Jurassic Smackover Formation of Alabama: American Association of Petroleum Geologists Bulletin, v. 78, no. 6, p. 938-959.

Kopaska-Merkel, D.C. and Schmoker, J.W., 1994, Regional porosity evolution in the Smackover Formation of Alabama: Carbonates and Evaporites, v. 9, no. 1, p.-58-75.

Kvenvolden, K.A., Carlson, P.R., Threlkeld, C.N., and Warden, Augusta, 1994, Carbon isotopic identification of two sources of oil residues in Prince William Sound, Alaska [abs.]: American Chemical Society 207th National Meeting, Preprints, v. 34, no. 1, p. 575.

Law, B.E. and Tennyson, M.E., 1994, Basin-centered gas accumulations in the Pacific Northwest-A potentially large source of energy [abs.]: American Association of Petroleum Geologists Annual Convention, Denver, 1994, Official program, v. 3., p. 194. 
Lee, M.W. and Agena, W.F., 1994, Applications of velocity-stack methods to seismic data processing: U.S. Geological Survey Bulletin 2102, 25 p.

Lee, M.W., and Göncz, Gábor, 1994, Vertical seismic profile experiments at the Békés-2 well, Békés basin, Hungary, in Teleki, P.G., and Kokai, J., eds., Basin analysis in petroleum exploration: Netherlands, Kluwer Academic Publishers, p. 257-275.

Lee, M.W., Hutchinson, D.R., Agena, W.F., Dillon, W.P., Miller, J.J., and Swift, B.A., 1994, Seismic character of gas hydrates on the southeastern U.S. Continental Margin: Marine Geophysical Researches Bulletin, v. 16, p. 163-184.

Lewan, M.D., 1994, Assessing natural oil expulsion from source rocks by laboratory pyrolysis, chap. 11 of Magoon, L.B., and Dow, W.G., eds., The petroleum systemFrom source to trap: American Association of Petroleum Geologists Memoir 60, p. 201-210.

Lewan, M.D., 1994, Determining ultimate petroleum potential of sedimentary basins by hydrous pyrolysis [abs.]: American Association of Petroleum Geologists Annual Convention, Denver, 1994, Official program, v. 3, p. 197.

Lewan, M.D., 1994, Effects of weathering on the reflectance of vitrinite in the Mowry Shale, Steinaker Reservoir, Utah , [abs.]: American Association of Petroleum Geologists Annual Convention, Denver, 1994, Official program, v. 3, p. 197.

Lewan, M.D., and Fisher, J.B., 1994, Organic acids from petroleum source rocks, chap. 4 of Pittman, E.D., and Lewan, M.D., eds., Organic acids in geological processes: Berlin Heidelberg, Springer-Verlag, p. 70-114.

Lewan, M.D., and Pittman, E.D., 1994, Introduction to the role of organic acids in geological processes, chap. 1 of Pittman, E.D., and Lewan, M.D., eds., Organic acids in geological processes: Berlin Heidelberg, Springer-Verlag, p. 1-21.

Lillis, P.G., 1994, Biomarkers as paleobathymetry indicators?-A case study from the Miocene marine rocks, central California [abs.]: American Association of Petroleum Geologists Annual Convention, Denver, 1994, Official program, v. 3., p. 198.

Lillis, P.G., 1994, A second petroleum system (?) in the Cuyama basin, California: American Association of Petroleum Geologists Bulletin, v. 78, no. 4, p. 668.

Lillis, P.G., 1994, Soda Lake-Painted Rock (!) petroleum system in the Cuyama basin, California, U.S.A., chap. 27 of Magoon, L.B., and Dow, W.G., eds., The petroleum system-From source to trap: American Association of Petroleum Geologists Memoir 60, p. 437-451.

MacMillan, Logan, Fouch, T.D., Nuccio, V.F., Rice, D.D., Schmoker, J.W., and Hartman, D.J., 1994, The Greater Natural Buttes producing area, southeastern Uinta Basin, Utah-A unique model for a basin-centered gas accumulation: The Outcrop, v. 43, no. 7, p. 3-4. 
MacMillan, Logan, Fouch, T.D., Nuccio, V.F., Rice, D.D., Schmoker, J.W., and Hartmann, D.J., 1994, The Greater Natural Buttes producing complex, southeastern Uinta Basin, Utah-A unique model for a basin-centered gas accumulation: Society for Sedimentary Geology, Rocky Mountain Section Newsletter, v. 19, no. 7, unpaginated.

Magoon, L.B., 1994, Petroleum resources in Alaska, chap. 30 of Plafker, G., and Berg, H.C., eds., The geology of Alaska: Boulder, Colorado, Geological Society of America, The Geology of North America, v. G-1, p. 905-936.

Magoon, L.B., 1994, The Tuxedni-Hemlock(!) petroleum system on Cook Inlet, Alaska, chap. 22 of Magoon, L.B., and Dow, W.G., eds., The petroleum system--From source to trap: American Association of Petroleum Geologists Memoir 60, p. 359-370.

Magoon, L.B., Castano, J.R., Lillis, P., MacKevett, N.H., and Naeser, N., 1994, Sacramento basin, California, petroleum systems-A case for long-range migration [abs.]: American Association of Petroleum Geologists Annual Convention, Denver, 1994, Official program, v. 3., p. 204.

Magoon, L.B., Castano, J.R., Lillis, P., MacKevett, N.H., and Naeser, N., 1994, Two petroleum systems in the Sacramento basin, California-A basis for new discoveries: American Association of Petroleum Geologists Bulletin, v. 78, no. 4, p. 669.

Magoon, L.B., and Dow, W.G., 1994, The petroleum system, chap. 1 of Magoon, L.B., and Dow, W.G., eds., The petroleum system-From source to trap: American Association of Petroleum Geologists Memoir 60, p. 3-24.

Magoon, L.B., and Dow, W.G., eds., 1994, The petroleum system-From source to trap: American Association of Petroleum Geologists Memoir 60, 645 p.

Magoon, L.B., and Valin, Z.C., 1994, An overview of the petroleum system case studies, chap. 20 of Magoon, L.B., and Dow, W.G., eds., The petroleum system-From source to trap: American Association of Petroleum Geologists Memoir 60, p. 329-338.

Malamud, B.D., Turcotte, D.L., and Barton, C.C., 1994, Fractal frequency-size analyses of floods in the upper Mississippi River basin [abs.]: EOS, Transactions of the American Geophysical Union, v. 75, no. 44, p. 2184.

Masters, C.D., 1994, Bibliography of the world energy resources program: U.S. Geological Survey Open-File Report 94-556, 12 p.

McLean, Hugh, and Stanley, R.G., 1994, Provenance of sandstone clasts in the lower Miocene Lospe Formation near Point Sal, California: U.S. Geological Survey Bulletin 1995-D,E, p. E1-E7.

Miller, J.J., Miller, J.A., and Potter, C.J., 1994, Seismic reflection studies in east-central Nevada [abs.]: Society of Exploration Geophysicists 64th Annual Meeting, Los Angeles, California, Expanded abstracts with biographies, p. 806. 
Miller, J.J., and Veges, István, 1994, Modeling seismic reflection data in the vicinity of the Békés -2 well, ch. 14 of Teleki, P.G. and others, eds., Basin Analysis in Petroleum Exploration: Netherlands, Kluwer Academic Publishers, p. 277-294.

Molenaar, C.M., Révész, I., Bérczi, A., Kovács, A., Juhasz, Gy. K., Gajdos, I., and Szanyi, B., 1994, Stratigraphic framework and sandstone facies distribution of the Pannonian sequence in the Békés basin , chap. 5 of Teleki, P.G., and others, eds., Basin analysis in petroleum exploration: Netherlands, Kluwer Academic Publishers, p. 99-110.

Moore, T.E., Wallace, W.K., Bird, K.J., Karl, S.M., Mull, C.G., and Dillon, J.T., 1994, Geology of northern Alaska, in Plafker, G., and Berg, H.C., eds., The Geology of Alaska: Boulder, Colorado, Geological Society of America, The Geology of North America, v. G-1, p. 49-140.

Moore, T.E., Wallace, W.K., Mull, C.G., Karl, S.M., and Bird, K.J., 1994, Generalized geologic map and sections for northern Alaska , in Plafker, G., and Berg, H.C., eds., the Geology of Alaska: Boulder, Colorado, Geological Society of America, The Geology of North America, v. G-1, pl. 6.

Nishenko, S.P., and Barton, C.C., 1994, Scaling laws for natural disasters-An application of fractal statistics to life and economic loss [abs.]: Santa Fe Institute Workshop on Natural Hazards Reduction, Santa Fe, New Mexico, 1994, Abstracts, p. 17.

Nishenko, S.P., and Barton, C.C., 1994 Scaling laws for natural disasters-Application of fractal statistics to life and economic loss data: Hazards Research and Applications Workshop, 19th, University of Colorado, Boulder, Colorado, 1994, p. R94-16.

Nuccio, V.F., 1994, Thermal history modeling in the Illinois basin [abs.]: Illinois Basin Energy and Mineral Resources Workshop, Evansville, Indiana, 1994, Proceedings, p. 28-29.

Nuccio, V.F., 1994, Vitrinite reflectance data for the Paleocene Fort Union and Eocene Wind River Formations, and burial history of a drill hole located in central Wind River basin, Wyoming: U.S. Geological Survey Open-File Report 94-220, 43 p.

Nuccio, V.F. and Dolton, G.L., 1994, Estimates of undiscovered conventional and unconventional oil resources on and near Indian and Native Lands of the United States [abs.]: Bureau of Indian Affairs Annual National Indian Energy/Minerals Conference, 4th, Denver, 1993, Abstracts and program, p. 5-6.

Nuccio, V.F., and Finn, T.M., 1994, Structural and thermal history of the Paleocene Fort Union Formation, central and eastern Wind River Basin, with emphasis on petroleum potential of the Waltman Shale Member [abs.]: Society of Organic Petrology Abstracts, v. 11, p. 75-76.

Nuccio, V.F., and Finn, T.M., 1994, Structural and thermal history of the Paleocene Fort Union Formation, central and eastern Wind River Basin, with emphasis on petroleum potential of the Waltman Shale Member, in Flores, R.M., Mehring, K.T., Jones, R.W., and Beck, T.L., eds., Organics and the Rockies Field Guide: Wyoming State Geological Survey Public Information Circular No. 33, p. 53-68. 
Nuccio, V.F. and Hatch, J.R., 1994, Potential problems using vitrinite reflectance to calibrate thermal history models in the Illinois basin [abs.]: American Association of Petroleum Geologists Annual Convention, Denver, 1994, Official program, v. 3., p. 226.

Oscarson, S.A., comp., 1994, Branch of Petroleum Geology Bibliography-1993: U.S. Geological Survey Open-File Report 94-206, 28 p.

Palacas, J.G., Flores, R.M., Keighin, C.W., and Anders, D.E., 1994, Origin of oil in oilsaturated sandstones in the upper part of the Fort Union Formation (Paleocene), Castle Gardens and Signor Ridge areas, Wind River Basin, Wyoming, in Flores, R.M., Mehring, K.T., Jones, R.W., and Beck, T.L., eds., Organics and the Rockies Field Guide: Wyoming Geological Survey Public Information Circular No. 33, p. 83-97.

Pawlewicz, M.J., 1994, Organic petrographic and Rock-Eval pyrolysis of Proterozoic Belt supergroup rocks, west central Montana: U.S. Geological Survey Open-File Report $94-155,10 \mathrm{p}$.

Pawlewicz, M.J. and Barker, C.E., 1994, An empirical determination of the minimum number of measurements to estimate the mean random vitrinite reflectance of disseminated organic matter [abs.]: American Association of Petroleum Geologists Annual Convention, Denver, 1994, Official program, v. 3., p. 231.

Perry, W.J., Jr., Flores, R.M. and Nichols, D.J., 1994, Transpressional gas-prone Paleogene basins of the northern Rocky Mountain region, a model for international exploration [abs.]: American Association of Petroleum Geologists Annual Convention, Denver, 1994, Official program, v. 3., p. 233.

Perry, W.J., Jr., and Frezon, S.E., 1994, Arkoma Basin province (116), in Powers, R.B., ed., Petroleum exploration plays and resource estimates, 1989, onshore United StatesRegion 7, Mid-Continent: U.S. Geological Survey Open-File Report 94-24, p. 34-44.

Perry, W.J., Jr., and Peterson, J.A., 1994, Pre-Oligocene structure of central Railroad Valley area and adjacent Pancake Range, Nevada western margin of the Paleogene Sheep Pass basin [abs.]: American Association of Petroleum Geologists Annual Convention, Denver, 1994, Official program, v. 3., p. 233.

Peterson, J.A., 1994, Eagle Springs no. 1-Nevada's February 1954 surprise , in Schalla, R.A., and Johnson, E.H., eds., Oil and gas fields of Nevada: Nevada Petroleum Society, p. 1-13.

Peterson, J.A., 1994, Regional geology and hydrocarbon resource potential, the Mediterranean Sea region: U.S. Geological Survey Open-File Report 94-166, 126 p.

Peterson, J.A., 1994, Regional geology of the eastern Great Basin and paleotectonic history of the Railroad Valley area, eastern Nevada, in Schalla, R.A. and Johnson, E.H., eds., Oil and gas fields of Nevada: Nevada Petroleum Society, p. 15-40. 
Peterson, J.A., 1994, Regional paleogeologic and paleogeographic maps of the Mesozoic Systems, Rocky Mountain region, U.S., in Caputo, M.V., Peterson, J.A., and Franczyk, K.J., eds., Mesozoic systems of the Rocky Mountain region, U.S.A: Society for Sedimentary Geology, Rocky Mountain Section, Special Publication, p. 65-71.

Piper, D.Z., and Isaacs, C.M., 1994, Minor element interpretation of deposition-Modern sediment and ancient shales [abs.]: Geological Society of America Annual Meeting, Seattle, 1994, Abstracts with program, v. 26, no. 7, p. A-23.

Piper, D.Z., and Isaacs, C.M., 1994, Seawater as a source of minor elements in black shales, phosphorites, and other sedimentary deposits [abs.]: Canadian Society of Petroleum Geologists Annual Meeting, Calgary, Canada, 1994, Abstract volume, unpaginated.

Pittman, E.D., and Lewan, M.D., eds., 1994, Organic acids in geological processes: Berlin Heidelberg, Springer-Verlag, $471 \mathrm{p}$.

Pittman, E.D., and Lewan, M.D., 1994, Preface, in Pittman, E.D., and Lewan, M.D., eds., Organic acids in geological processes: Berlin Heidelberg, Springer-Verlag, 1 p.

Pollastro, R.M., 1994, Clay diagenesis and mass balance-The forest and the trees: Clay and Clay Minerals, v. 42, no. 1, p. 93-97.

Pollastro, R.M., and Bohor, B.F., 1994, The Cretaceous/Tertiary boundary unit, western interior of North America-A record of large meteorite impact and regional diagenesis , in Caputo, M.V., Peterson, J.A., and Franczyk, K.J., eds., Mesozoic systems of the Rocky Mountain Region, USA: Denver, Rocky Mountain Section, Society for Sedimentary Geology, p. 523-536.

Powers, R.B., ed., 1994, Geologic framework, in Powers, R.B., ed., Petroleum exploration plays and resource estimates, 1989, onshore United States-Region 7, MidContinent: U.S. Geological Survey Open-File Report 94-24 , p. 9-10.

Powers, R. B., ed., 1994, Petroleum exploration plays and resource estimates, 1989, onshore United States-Region 7, Mid-Continent: U.S. Geological Survey Open-File Report 94-24, $101 \mathrm{p}$.

Prensky, S.E., 1994, Bibliography of well-log applications, annual update-October 1, 1993 to September 30, 1994: U.S. Geological Survey Open-File Report 94-652A,B,C, 203 p.

Prensky, S.E., 1994, Capabilities of MWD tools broadened by advances: American Oil and Gas Reporter, v. 37, no. 10, p. 35-41.

Prensky, S.E., 1994, Salina Basin province (121), in Powers, R.B., ed., Petroleum exploration plays and resource estimates, 1989, onshore United States-Region 7, MidContinent: U.S. Geological Survey Open-File Report 94-24, p. 69-70.

Prensky, S.E., 1994, A survey of recent developments and emerging technology in well logging and rock characterization: The Log Analyst, v. 35, no. 2, p. 15-45. 
Prensky, S.E., 1994, A survey of recent developments and emerging technology in well logging and rock characterization-A supplement: The Log Analyst, v. 35, no. 5, p. 78-84.

Prensky, S.E., and Anderson, Barbara, 1994, SPWLA computer index: The Log Analyst, v. 35 , no. 6, p. 60-65.

Prensky, S.E., and Anderson, Barbara, 1994, SPWLA computer index: Society of Professional Well Log Analysts 35th Annual Symposium, Tulsa, 1994, Transactions, v. $1,7 \mathrm{p}$.

Prensky, S.E., and Anderson, Barbara, 1994, SPWLA digital citation index [abs.]: The Log Analyst, v. 35, no. 2, p. 104.

Price, L.C., 1994, Basin richness and source rock disruption-A fundamental relationship?: Journal of Petroleum Geology, v. 17, p. 5-38.

Price, L.C., 1994, Metamorphic free-for-all: Nature, v. 370, p. 253-254, 285-287.

Price, L.C., and LeFever, J., 1994, Dysfunctionalism in the Williston basin-The Bakken/ mid-Madison petroleum system: Canadian Petroleum Geology Bulletin, v. 42, no. 2, p. 187-218.

Rice, D.D., 1994, Potential for natural gas resources on Indian and Native Lands of the United States [abs.]: National Indian Energy/Minerals Conference, 4th, Denver, 1994, Program with abstracts, unpaginated.

Ridgley, J.L., and Nuccio, V.F., 1994, Mississippian St. Louis Limestone-A new source-rock play in the Illinois basin? [abs.]: American Association of Petroleum Geologists Annual Convention, Denver, 1994, Official program, v. 3., p. 243.

Rubin, D.M., Schmidt, J.C., Anima, R.A., Brown, K.M., Hunter, R.E., Ikeda, Hiroshi, Jaffe, B.E., McDonald, R.R., Nelson, J.M., Reiss, T.E., Sanders, Rex, and Stanley, R.G., 1994, Internal structure of bars in Grand Canyon, Arizona, and evaluation of proposed flow alternatives for Glen Canyon Dam: U.S. Geological Survey Open-File Report 94-594, $56 \mathrm{p}$.

Ryder, R.T., 1994, Black Warrior Basin province (130), in Powers, R.B., ed., Petroleum exploration plays and resource estimates, onshore United States-Region 8, Eastern Interior; Region 9, Atlantic Coast: U.S. Geological Survey Open-File Report 94-211, p. 62-66.

Ryder, R.T., 1994, Cincinnati Arch province (129), in Powers, R.B., ed., Petroleum exploration plays and resource estimates, 1989, onshore United States-Region 8, Eastern Interior; Region 9, Atlantic Coast: U.S. Geological Survey Open-File Report 94-211, p. 54-61. 
Ryder, R.T., 1994, The Knox unconformity and adjoining strata, western Morrow County, Ohio, in Shafer, W.E., ed., The Morrow County, Ohio "oil boom"; 1961-1967 and the Cambro-Ordovician Reservoir of central Ohio: Ohio Geological Society, p. 249-271.

Ryder, R.T., Miller, J.J., Grow, J.A., and Ratcliffe, N.M., 1994, Interpreted reflection seismic events near the North Central Corporation well, Newark basin, Bucks County, Pennsylvania [abs.]: Society of Exploration Geophysicists 64th Annual Meeting, Los Angeles, 1994, Expanded abstracts with biographies, p. 807.

Ryder, R.T., Miller, J.J., Grow, J.A., and Ratcliffe, N.M., 1994, Interpreted seismic reflection events near the North Central Oil Corporation well, Newark basin, Bucks County, Pennsylvania [abs.]: American Association of Petroleum Geologists Annual Convention, Denver, 1994, Official program, v. 3., p. 248.

Ryder, R.T., Rice, D.D., Sun, Zhaocai, Zhang, Yigang, Qiu, Yunyu, and Guo, Zhengwu, 1994, Petroleum geology of the Sichuan basin, China-Report on U.S. Geological Survey and Chinese Ministry of Geology and Mineral Resources field investigations and meetings, October 1991: U.S. Geological Survey Open-File Report 94-426, 67 p.

Saouma, V.E. and Barton, C.C., 1994, Fractals, fractures, and size effects in concrete: Journal of Engineering Mechanics, v. 120, no. 4, p. 835-854.

Schalla, R.A., Barker, C.E., and Newmann, W.H., 1994, Hot water and oil from a shallow exploratory borehole, Buena Vista Valley, Pershing Co., Nevada, in Schalla, R., and Johnson, E., eds., Oil fields of the Great Basin: Nevada Petroleum Society Special Publication, p. 127-130.

Schmoker, J.W., 1994, Volumetric calculation of hydrocarbons generated, chap. 19 of Magoon, L.B., and Dow, W.G., eds., The petroleum system-From source to trap: American Association of Petroleum Geologists Memoir 60, p. 323-326.

Schmoker, J.W., and Schenk, C.J., 1994, Regional porosity trends of the Upper Jurassic Norphlet Formation in southwestern Alabama and vicinity, with comparisons to formations of other basins: American Association of Petroleum Geologists Bulletin, v. 78 , no. 2 , p. $166-180$.

Sorlien, C.C., Nicholson, C., Luyendyk, B.P., Cisowski, S., Bird, K.J., and Tennyson, M.E., 1994, Miocene extension and rotation of south-central California [abs.]: American Association of Petroleum Geologists Bulletin, v. 78, no. 4, p. 675.

Spencer, C.W., 1994, Abnormal formation pressures caused by hydrocarbon generationExamples from Rocky Mountain region, in Fertl, W.H., Chapman, R.E., and Holtz, R.F., eds., Studies in abnormal pressures, Developments in Petroleum Science, 38: Amsterdam, Elsevier, p. 343-375.

Spencer, C.W., Law, B.E., Meissner, F.F., and Slavin, V.I., 1994, Overview of worldwide occurrence of abnormal reservoir pressures [abs.]: American Association of Petroleum Geologists Hedberg Research Conference, Denver, Colorado, 1 p., unpaginated. 
Spencer, C.W., Szalay, Arpád, and Tatár, Eva, 1994, Abnormal pressure and hydrocarbon migration in the Békés basin, in Teleki, P.G., and others, eds., Basin analysis in petroleum exploration: Netherlands, Kluwer Academic Publishers, p. 201-219.

Stanley, R.G., Cotton, Mary Lou, Bukry, David, Filewicz, M.V., Valin, Z.C., and Vork, D.R., 1994, Stratigraphic revelations regarding the Rincon Shale (lower Miocene) in the Santa Barbara coastal area, California: American Association of Petroleum Geologists Bulletin, v. 78, no. 4, p. 668.

Stanley, W.D., Johnson, S.Y., and Nuccio, V.F., 1994, Analysis of deep seismic reflection and other data from the southern Washington Cascades: U.S. Geological Survey OpenFile Report 94-159, 5 p.

Tebbens, S.F., Barton, C.C., and Nishenko, S.P., 1994, Scaling laws for tsunamis [abs.]: Gordon Research Conference, San Miniato, Italy, 1994, p. 15.

Tebbens, S.F., and Barton, C.C., 1994, Scaling and forecasting of tsunamis [abs.]: EOS, Transactions of the American Geophysical Union, v. 75, no. 44, p. 357.

Tennyson, M.E. and Beeman, W.R., 1994, Digital geologic compilation of Santa Maria 30' x 60 ' quadrangle, California-Status and structural interpretations [abs.]: Geological Society of America Abstracts with programs, v. 26, no. 2, p.-98.

Thorez, J., Flores, R.M., Bossiroy, D., Keighin, C.W., Caudron, M., and Kalbusch, S., 1994, Source-rocks, sedimentary and pedogenetic distribution, diagenetic evolution in reservoir and seal rocks of clay assemblages in intermontane, tectonically-controlled Paleocene coal basins, Wyoming, Montana, and North Dakota, U.S.A. [abs.]:

Conference on Clay Mineralogy and Petrology, 13th, Prague, Czech Republic, 1994, p. 116.

Ulmishek, G.F., 1994, Independent petroliferous system revisited [abs.]: American Association of Petroleum Geologists Research Conference, Mexico City, 1994, unpaginated.

Ulmishek, G.F., Bogino, V.A., Keller, M.B., and Poznyakevich, Z.L., 1994, Structure, stratigraphy, and petroleum geology of the Pripyat and Dnieper-Donets basins, Byelarus and Ukraine, chap. 4 of Landon, S.M., ed., Interior Rift Basins: American Association of Petroleum Geologists Memoir 59, p. 125-156.

Ulmishek, G.F., and Magoon, L.B., III, 1994, The petroleum system-Concept and applications: Fourteenth World Petroleum Congress, 1994, Proceedings, p. 1-9.

Vedder, J.G., Howell, D.G., and McLean, Hugh, 1994, Preliminary geologic map of Bates Canyon quadrangle and part of Peak Mountain: U.S. Geological Survey Open-File Report 94-128. 
Vedder, J.G., McLean, Hugh, and Stanley, R.G., 1994, New 1:24,000-scale geologic maps show stratigraphic and structural relations that require reinterpretation of Cretaceous and Cenozoic tectonic events in the Sierra Madre-San Rafael Mountains area, California [abs.]: Geological Society of America Abstracts with programs, v. 26, no. 2, p. 100-101.

Viger, R.J., and Schenk, C.J., 1994, GIS and its role in the USGS National oil and gas assessment [abs.]: GIS in the Rockies Meeting, Golden, Colo., 1993, Proceedings, unpaginated.

von Huene, R., Klaeschen, D., Cropp, B., and Miller, J.J., 1994, Tectonic structure across the accretionary and erosional parts of the Japan Trench Margin [abs.]: Journal of Geophysical Research, v. 99, no. B11, unpaginated. 